\title{
The Utilization of Wastewater from Palm Oil Industry As Culture Medium for Microalgae (Chlorella sp) That Can be Used As Supplement Food for Calves in Riau Province
}

\author{
Tengku Dahril ${ }^{1}$, Aras Mulyadi ${ }^{2}$ and Efawani $^{3}$ \\ $\left\{\right.$ dahril2011@gmail.com $\left.{ }^{1}\right\}$ \\ ${ }^{1,3}$ Department of Aquatic Resources Management, Faculty of Fisheries and Marine Science, \\ University of Riau, Pekanbaru, Riau, Indonesia. \\ ${ }^{2}$ Department of Marine Science, Faculty of Fisheries and Marine Science, University of \\ Riau, Pekanbaru, Riau Indonesia.
}

\begin{abstract}
Palm oil industries has been developing quickly in Riau Province. Right now, at least, 246 palm oil industries present in through around of district in Riau Province. They discharges not only liquid waste in vast amount but also solid and gas. Thy liquid waste is rich in micro and macro nutrient that can be used as culture medium of microalgae (Chlorella sp). The study of utilization of wastewater from oil palm industry as culture medium for microalgae (Chlorella $\mathrm{sp}$ ) that can be used as supplement food for calves in Riau Province was conducted from July to August 2017. Result of this study indicated that supplement food of Chlorella powder can promote the growth and production of calves in Riau Province. After 12 weeks calves cultured in the cattle, the mean weight of them increased from $125,0 \mathrm{~kg}$ to 150,0 or increased as much as $25 \mathrm{~kg}$ compared by without supplement food was $115.6 \mathrm{~kg}$ in initial study to $129.0 \mathrm{~kg}$ after 12 weeks or increased only $13.4 \mathrm{~kg}$. based on this study, it concluded that wastewater from palm oil industry can promote the growth and production of Chlorella sp that can be used as supplement food for calves in Riau Province
\end{abstract}

Keywords: Palm Oil waste, Chlorella sp., Supplement food, Calves.

\section{Introduction}

Riau is a large number of palm oil plantations in Indonesia with areas of 2.399.173 ha in 2014. The production of Crude Palm Oil (CPO) reached 7.047.221 ton in 2014 produced by 246 of Palm Oil Industries. The Palm Oil Industry generates large quantity of wastes whose disposal is a challenging task. They also gives rise to highly polluting waste-water, known as Palm Oil Mill Effluent (POME), wise is often discharge in disposal ponds, resulting in the leaching of contaminants that pollute the groundwater and soil, and release of methane gas into the atmosphere. POME could be used for biogas production through anaerobic digestion.

In a conventional Palm Oil Mill, 500-700 kg of Pome is generated for every ton of processes fresh fruits bunches (FFB). Most of the Biomass residues from Palm Oil Mills are either burnt in the open or disposed off in waste ponds. The Palm Oil Industry, therefore contributes significantly to global climate change by emitting carbon dioxide and methane

Wastewater production from all palm oil industries in Riau is estimated to be 29.250.000 ton/year (Riaupos, Sunday, 30 August 2015). This wastewater contain biological oxygen 
demand (BOD) estimated to 8,200-35,00 mg/l, Chemical Oxygen Demand (COD), 15,103 $65,100 \mathrm{mg} / \mathrm{l}$, Total Solid Suspended(TSS) estimated to be 1,220-50,700 mg/l, oil and lipid estimated to $150-14,700 \mathrm{mg} / \mathrm{l}$ (Dirjen PPHP, 2006). Therefore, it is very important to conduct a research to eliminate the effect of wastewater Oil Palm Industry in Riau province.

Chlorella is a potential supplement food source for calves because it is high protein and other essential nutrients when dried, it s about $45 \%$ protein, $20 \%$ fat, $20 \%$ carbohydrate, $5 \%$ fiber, and $10 \%$ minerals. It is also abundant in calories and vitamins. Chlorella is also suggested as an inexpensive protein supplement to human and animal diet. Under certain growing condition, Chlorella yields oils that are high in poly saturated fats

Chlorella is a pioneer organisms living in the ocean for along periods of time. They are (sun) light driven cell factories that transform carbon dioxide $\left(\mathrm{CO}_{2}\right)$ into ingredient for feed and food, free Oxygen $\left(\mathrm{O}_{2}\right)$, and biomass for feed stock and bio-fuels. They can grow fast under extreme condition (salt, freshwater, alkaline, hot etc, yield up to 10 times that of traditional crop and do not compete with traditional crops for food, and can be used marginal land. They can absorb many in-organic materials from wastewater such as nitrogen, phosphore, kalium, magnesium, ferum, and others so they can be able to clean the dirty water (purify). In this study we use wastewater from palm oil industries to grow and produce Chlorella sp in order to used as supplement food for calves in Riau Province.

\section{Material and Methods}

This study was conducted in three steps. Step one we call a initial study with high concentration of palm oil wastewater, and the second steps with low concentration of wastewater. Wastewater from Palm Oil Industry belong to PTPN 5 Tandun, Kampar, Riau was collected and filtered with Dahril Filter. Dahril filter is a tool specially designed to filter the palm oilmill effluent (wastewater). Dahril filter was made by a plastic drum with gravel, sand, coal and palm fibres inside. The Dahril filter was filled with wastewater through filter substrate than the wastewater was boiled as long as 20 minute to kill bacteria and fungi. This filtered wastewater was put in 400-ml plastic bottle, that call it Dahril Solution 2, that can be used in this experiment. This wastewater was diluted by adding distilled water with the concentration of $0,0 \%, 25 \%, 50 \%, 75 \%$, and $100 \%$ as prelimenary study in $400 \mathrm{ml}$ - culture medium.

Chlorella sp. Obtained from Freshwater Aquaculture Research Center, Depok, West Java, was inoculated with initial density of $5 \times 10^{4}$ cells $/ \mathrm{ml}$ in $600 \mathrm{ml}$ flasks for each treatment. All growth studies were conducted in triplicate. Algae were cultured in a simple incubator with continuous aeration, illuminated by two daylight fluorescent lamps with a light intensity of 4000 lux and temperature between 23 to $28^{\circ} \mathrm{C}$. The algae density was enumerated daily for 15 $\mathrm{d}$ using a thomacytometer under a binocular microscope.

Based on the result of the study in treatment $\mathrm{I}$, the study was continued with low concentration of wastewater namely $10 \%, 20 \%$ and $30 \%$, and $0 \%$ as control. The study was conducted in 61 -plastic bottle with culture medium 41 each treatments and continuously aerated in outdoor room. The light come from sunlight directly with room temperature about 28 to $33^{\circ} \mathrm{C}$.. Chlorella was inoculated with initial density of $5 \times 10^{4}$ cells $/ \mathrm{ml}$. The number of algae cells was enumerated daily for $22 \mathrm{~d}$ using thomacytometer under binocular microscope. After 22 days culture periods, all biomass of Chlorella were harvested and dry weight of algae were measured using a balanced (weighing). Concentration of nitrate and phosphate before and after algae culture were also measured. 
All biomass that collected from the second study was used to make cow biscuit as supplement food for calves in the third step of this study. This biscuit it call LOMAK was made by, $3 \%$ Chlorella powder mix with $50 \%$ of sago powder, $20 \%$ wheat flour, $20 \%$ green pea powder, $5 \%$, white sugar powder, $2 \%$ of Pandanus leaf with local name daun pandan wangi, butter, vitamin (BECOM-C) and 2 eggs. One biscuit of this supplement food with average weight about 12,5 gram each, was given to three calves daily in the morning, before their eat normally, and three of them none as long as 12 weeks during the period of this study. Mean weight of each calf was measured weekly to know the effect of supplement food to growth and production of calves.

\section{Result and Discussion}

It was founded that wastewater from palm oil industry in Riau Province supported the growth of Chlorella sp. The best growht of Chlorella was founded in the low concentration of wastewater $(25 \%)$ conpared with high concentration $(50 \%, 75 \%$ and $100 \%)$., with total density of $3,3 \times 10^{6}$ cells/ml at day 13 (fig 1)

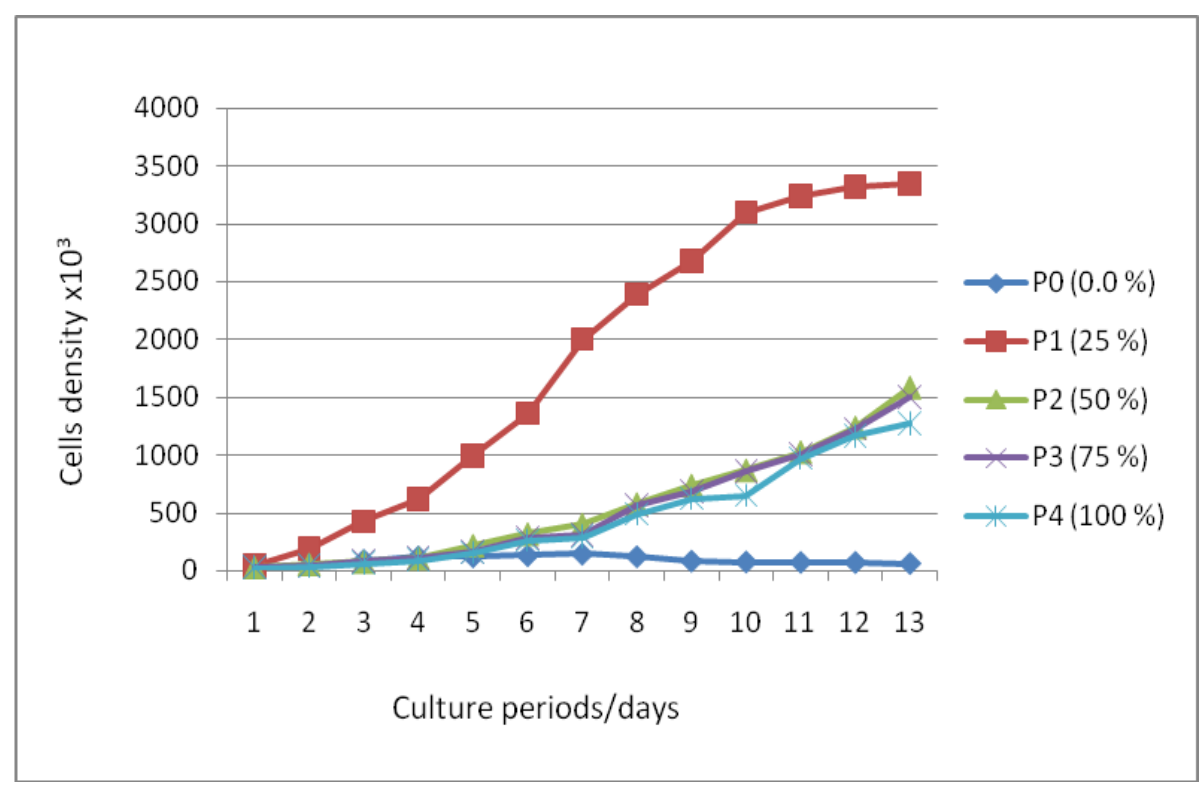

Fig 1. Growth of Chlorella sp with high concentration of palm oil wastewater

Based on the result of this preleminary study, the experiment was continued with the concentration of $10 \%, 20 \%$, and $30 \%$. The result of second experiment, it was founded that concentration of $20 \%$ of wastewater was better compare with concentration of $10 \%$ and $30 \%$. High concentration of Chlorella sp was found in 22 days with total density of $6.6 \times 10^{6}$ cells/ml as shown in fig 2 . 


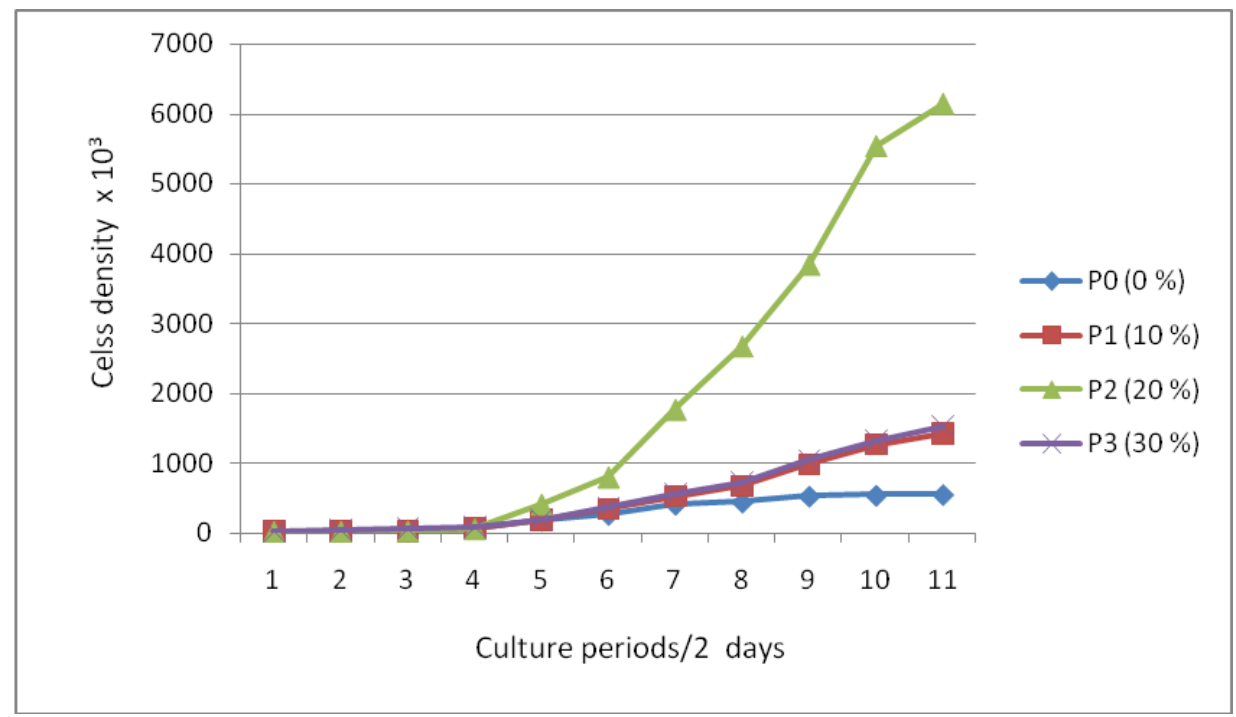

Fig 2. Growth of Chlorella sp with low concentration of palm oil waste water.

At the end of this second study, the total density and biomass of Chlorella were also found higher in the concentration of $20 \%$ with total number of $6.6 \times 10^{6} \mathrm{cell} / \mathrm{ml}$ and biomass, $0.36 \mathrm{gr} / 1$ as shown in tabel 1 .

Table 1. Total cell density and biomass at the end the study

\begin{tabular}{lcl} 
& & \\
Treatmens & Cell density $($ Cells/ml) & Biomass $(\mathrm{gr} / \mathrm{l})$ \\
\hline P0 $(0 \%)$ & 550.667 & 0.05 \\
P1 $(10 \%)$ & 1.422 .000 & 0.17 \\
P2 $(20 \%)$ & 6.145 .333 & 0.36 \\
P3 $(30 \%)$ & 1.524 .000 & 0.18
\end{tabular}

The biomass of Chlorella that collected from the second study has been used as supplement food for calves. Result of this study indicated that supplement food with $3 \%$ of Chlorella contain can promote the growth and production of calves in Riau Province. After 12 weeks calves cultured in the cattle with supplement food given every day, the mean weight of calves increase from $125.0 \mathrm{~kg}$ to $150.0 \mathrm{~kg}$ or added as much as $25.0 \mathrm{~kg}$ compared with without supplement food was $115.6 \mathrm{~kg}$ in initial study to $129.0 \mathrm{~kg}$ or added only about $13.4 \mathrm{~kg}$. Based on this research result, it can be known that wastewater from Palm oil industry can promote the growth and production of Chlorella sp, that can be used as supplement food for calves in Riau Province. 
Table 2. The weight $(\mathrm{kg})$ of calves witout and with supplement food before and after cultivated for 12 weeks

\begin{tabular}{|c|c|c|}
\hline Before & 115.6 & 125.0 \\
\hline After & 129.0 & 150.0 \\
\hline Added & 13.4 & 25.0 \\
\hline
\end{tabular}

Many studies have been reported that nitrogen and phosphore are the two main nutrients that can influence phytoplankton growth (Finenko and Akinnina 1974: Febregas et al 1986. Dahril, Ahmad and Iizuka, (1995 and 1998) reported that human manure and animal manures with contain high concentration of nitrogen and phosphore can support the growth and production of freshwater green algae (Chlorella sp) in bath culture medium. In this study, we also found that green algae, Chlorella sp can growth properly in palm oil wastewater and it can be also used as supplement food for calves. They can also decreased nitrate and phosphate in wastewater contain,. Theyfore, Chlorella sp can be used efectively to decrease nitrogen and phosphore in wastewater of palm oil industry in Riau province. The concentration of nitrate and phosphate before and after chlorella growth in many concentration of wastewater from plam oil industry can be shown in tabel 3 follows.

Table 3. Mean concentration of nitrate and phosphate before and after Chlorella cultured in each treatments.

\begin{tabular}{lcccccc} 
Treatments & \multicolumn{3}{c}{ Nitrate $(\mathrm{mg} / \mathrm{l})$} & \multicolumn{3}{c}{ Phosphate $(\mathrm{mg} / \mathrm{l})$} \\
Before & After & Decreased & Before After & \multicolumn{2}{c}{ Decreased } \\
\hline P0 $(0 \%)$ & 4.1 & 0.4 & 3.7 & 0.40 & 0.09 & 0.31 \\
P1 $(10 \%)$ & 7.7 & 3.3 & 4.0 & 0.83 & 0.11 & 0.72 \\
P2 $(20 \%)$ & 13.8 & 2.4 & 11.4 & 1.16 & 0.17 & 0.99 \\
P3 $(20 \%)$ & 18.4 & 11.8 & 6.6 & 1.38 & 0.64 & 0.74 \\
\hline
\end{tabular}

\section{Conclusion}

Based on this study we can conclusion that wastewater from Palm Oil Industry can promote the growth and production of microalgae Chlorella sp. That can be used as supplement food for calves. High growth and biomass production of Chlorella was found in the concentration of $20 \%$ of wastewater with cell density of $6.6 \times 10^{6}$ cell $/ \mathrm{ml}$ and biomass, $0.36 \mathrm{gr} / \mathrm{l}$. Than, Chlorella biomass can be used as supplement food to increase the growth and production of calves. The utilization of Chlorella $\mathrm{sp}$ in wastewater from palm oil industry also can decrease the concentration of nitrate from 13.8 to 2.4 , and phosphate from 1.16 to 0.17 $\mathrm{mg} / \mathrm{l}$. Therefore, Chlorella sp beside can be used as food supplement for animal husbandry, they can also eliminate water pollution from palm oil industry wastewater in Riau Province 


\section{Acknowledgement}

This study was supported by Ministry of Research, Technology and High Education, Republic of Indonesia, Jakarta. We wish to thanks Head of Research and Society Dedication League, University of Riau and Dean of Faculty of Fisheries and Marine Science, University of Riau for kindly supported this works. We also would like to thanks to Director of PT PTP 5 and some of our students with their dedication to support this study

\section{References}

[1] Dahril, T. M. Ahmad and S. Iizuka. 1995. Effect of Human Excreta on the Growth of a Freshwater Green Algae (Chlorella sp) and a Rotifer (Brachionus calyciflorus). Asian Fisheries Science 8 (1) 41-46.

[2] Dahril. T. M. Ahmad and S. Iizuka. 1998. Effect of Various Animal Manures on the Grwowth of a Freshwater Green Algae (Chlorella sp) and Rotifer (Brachionus calyciflorus). Asian Fisheries Science (1) : 191 -201.

[3] Dahril, T.A. Mulyadi and Efawani. 2016. Pemanfaatan limbah cair pabrik kelapa sawit sebagai media kultur mikroalga (Chlorella $\mathrm{sp}$ ) dalam fotobioreaktor untuk mencegah pencemaran lingkungan perairan di Provinsi Riau. Research Report. 20 halaman (unpublished).

[4] Fahregas, J.herrero, B. Cabezas and J. Abaide. 1986. Biomass production and biochemical composition in mass cultures of the marine microalgae Isochrysis galbana Parke at varying nutrient concentration. Aquaculture $53: 101-113$.

[5] Finenko, ZZ. And D.K.E. Akina. 1974. Effect of in organic phosphores on the growth rate of diatom. Marine Biology $20: 193-201$. 